\title{
The Effect of Corporate Governance on the Cost of Debt: Evidence from Thailand
}

\author{
Kulaya JANTADEJ ${ }^{1}$, Woraphon WATTANATORN ${ }^{2}$
}

Received: July 03, 2020 Revised: July 25, 2020 Accepted: August 10, 2020

\begin{abstract}
Although the corporate governance plays a crucial role in protecting shareholder wealth, the effect of corporate governance on cost of debt is unclear. On one hand, the corporate governance reduces asymmetric information between corporate and external investor including debtholder leading to a decreasing in cost of debt financing. On the other hand, bondholders require higher rate of return for an improvement corporate governance. Hence, this study aims to investigate the relationship between the mechanism to improve corporate governance namely board effectiveness and the cost of debt in an emerging market. As we aim to explore the relationship between cost of debt and board effectiveness, we select corporation in Thailand as our sample because the businesses in Thailand are major debt-financing. Hence, our sample include listed firm in Stock Exchange of Thailand between 2007 and 2016. Our main findings support the sub-optimal investment hypothesis in that improved board effectiveness is associated with higher cost of borrowing. In addition, we find that the number of board member-board size, the number of board meeting, and the percentage of non-executive on audit committee play are positively associated with the cost of debt financing. Furthermore, we perform two-stage-least square (2SLS) to ensure that our results are far from endogeneity issue.
\end{abstract}

Keywords: Cost of Debt, Corporate Governance, Board Effectiveness, Thailand Stock Exchange

JEL Classification Code: G30, G32, G34, G38

\section{Introduction}

Little is known about an impact of internal corporate governance mechanism on the cost of debt financing, which most prior evidence is documented in Anglo-Saxon countries and shows contradicting findings (Ghouma et al., 2018; Hashim \& Amrah, 2016; Bradley \& Chen, 2015; Jiraporn et al., 2013; Fields et al., 2012; Pham et al., 2012; Lorca et al., 2011; Ashbaugh-Skaife et al., 2006; Klock et al., 2005; Bhojraj \& Sengupta, 2003; Han, Kang, \& Shin, 2016;

${ }^{1}$ First Author. Assistant Professor in Accounting, Department of Accounting, Thammasat Business School, Thammasat University, Thailand. Email: kulaya@tbs.tu.ac.th

${ }^{2}$ Corresponding Author. Lecturer in Finance, Department of Finance, Thammasat Business School, Thammasat University, Thailand [Postal Address: 2 Phra Chan Road, Phra Borom Maha Ratchawang, Phra Nakhon, Bangkok 10200, Thailand]

Email: woraphon@tbs.tu.ac.th

(c) Copyright: The Author(s)

This is an Open Access article distributed under the terms of the Creative Commons Attribution Non-Commercial License (https://creativecommons.org/licenses/by-nc/4.0/) which permits unrestricted non-commercial use, distribution, and reproduction in any medium, provided the original work is properly cited.
Vijayakumaran \& Vijayakumaran, 2019a; Vijayakumaran \& Vijayakumaran, 2019b). The board of directors as an important part of internal corporate governance plays roles in major corporate's decision makings, which duties of corporate boards include advising and monitoring management, and protecting shareholders' interests (Lin et al., 2014; Bhojraj \& Sengupta, 2003). However, a benefit of shareholders might be different from that of debtholders and shareholders allied with management tend to transfer wealth of debtholders to shareholders (Pham et al., 2012; Denis \& McConnell, 2003; Jensen \& Meckling, 1976), subsequently causing the agency cost of debt. Thus, the quality and effectiveness of the board of directors have a power on the cost of debt financing.

A number of studies on impacts of corporate governance on bondholders' wealth are investigated, though the results remain mixed. On the supporting side on a reduction in the agency cost, Sengupta (1998) shows that an improvement in corporate governance reduces asymmetric information between corporate and external investors, including debtholders, yielding a lower cost of debt financing. This is reconfirmed by Ashbaugh-Skaife, Collins, and LaFond 
(2006). On the other side, Klock et al. (2005), Ortiz-Molina (2006), and Jiraporn et al. (2015) find that bondholders require higher rate of return for an improvement corporate governance. In summary, it remains unclear that the corporate governance mechanisms that are advantageous to shareholders are not necessarily good to bondholders.

Effectiveness of corporate board is enhanced by board monitoring activities such as the board meeting (Lin et al., 2014; Brick \& Chidambaran, 2010; Vafeas, 1999). The board meeting is an important channel for board members to receive and discuss on corporate information, provide their advices and constructive comments, and also monitor performance of management (Garner et al., 2017; Lin et al., 2014; Adam $\&$ Ferreira, 2008). A failure to attend the meeting results in the lower quality of monitoring by the board of directors. In addition, the board meetings are beneficial to shareholders (Brick \& Chidambaran, 2010; Vafeas, 1999). Lorca et al. (2011) find that the number of annual board meetings has an influence on the cost of debt.

A frequency of board meeting is a main vehicle for the board of directors to obtain corporate information, make a decision, and monitor the management (Adams \& Ferreira, 2008). Thus, the attendance rate of the directors in the board meeting is another board attribute that captures work effort and the attention of broad members (Lin et al., 2014; Chou et al., 2013). Hence, failure to attend the meeting might result in the lower quality of monitoring by board of directors. Lin et al. (2014) find that failure to attend the board meetings may affect the effectiveness of the board, exacerbate the agency cost between shareholders and management, and eventually has inversely influenced on firms' accounting performance. In addition, Vafeas (1999), Brick and Chidambaran (2010), Lin et. al. (2014) demonstrate that the number of annual board meeting and attendance rate have a significant impact on the board effectiveness and firm performance.

Even though notable roles of board characteristics on the shareholder-management agency cost are widely studied, none has investigated those of on the agency cost of debt, especially in developing countries. This is a crucial issue in our sample setting, i.e., Thailand, because businesses in Thailand usually finance through using bank loan and debt securities. Therefore, the primary objective of this research is to explore the effect of corporate governance from the bondholders' point of view.

The paper contributes to prior studies in twofold. First, to the best of our knowledge, this is the first study to examine how the attendance rate of board meetings affects the corporate's weighted average cost of debt. Second, we fill the gap in the literature by investigating the business operations in Thailand, which rely on the debt financing (Prommin et al., 2014; Wattanatorn \& Nathaphan, 2019; Wattanatorn et al., 2020). The unique characteristic on using debt as a major source of funds distinguishes our study from others on developed markets, in which possess less incomplete market structure, less severe asymmetric information, lower political and economic uncertainty, stronger regulation, and higherquality auditing systems. Findings in this study, therefore, generalize to the debt-heavily financing economies.

We find that the better the effectiveness of the board of directors is, the higher the cost of the debt financing. The findings support the sub-optimal investment hypothesis, suggesting that the better the quality of governance, the higher the cost of debt for the firm. The findings remain unchanged after taking an endogeneity problem into consideration. Overall, the results are consistent with the findings of Jiraporn et al. (2013).

The remainder of the study is as follows. Section 2 provides theoretical framework in addition to the research hypotheses. Section 3 demonstrates data sources while section 4 provides research methodology. Section 5 discusses on the result of this study and possible endogeneity issues. The last section presents the conclusion and summary of this study.

\section{Theoretical Framework and Hypothesis Development}

\subsection{Agency Cost of Debt}

Agency cost of debt occurs when debtholders face threats from both shareholders and management. Shareholders allied with management are likely to engage in expropriating wealth from debtholders to themselves (Ghouma et al., 2018; Lasfer, 1995; Jensen \& Meckling, 1976; Fama \& Miller, 1972). The wealth transfer happens in two cases. First, shareholders tend to sub-optimally invest the capital that is raised from debtholders in very risky projects (Vegas projects). If the projects succeed, shareholders earn large benefits. If not, debtholders have to largely bear the costs of the failure. This is so called the overinvestment problem. Second, shareholders decide not to invest in some positive projects if they realize that returns on such projects are all taken by debtholders, so called the underinvestment problem.

\subsection{Effect of the Board Characteristic to the Agency Theory}

The board of directors is considered as a governance mechanism (Denis \& McConnell, 2003; Jensen, 1993) that are responsible for monitoring firm performance and for acting as a guard of the shareholders' benefits (Lin et al., 2014; Bhojraj \& Sengupta, 2003). How effectiveness of corporate boards impacts the agency cost of debt is relied on the perception of debtholders towards the board effectiveness (Fields et al., 2012; Lorca et al., 2011; Klock 
et al., 2005). In case debtholders believe that effective corporate boards improve firm performance in the way that both shareholders and debtholders jointly gain their benefits, an improvement in the effectiveness of corporate boards would lead to a reduction in required rate of return of debtholders, and thereby lowering the cost of corporate debt. On the other hand, when debtholders are less favored than shareholders by corporate boards and the benefits of debtholders and those of shareholders differ, debtholders would require a higher rate of return, causing a high corporate cost of debt.

Previous studies demonstrate conflicting evidence on the association between board effectiveness and the cost of debt. Fields et al. (2012), Pham et al. (2012), and Anderson et al. (2004) find an inverse relationship between the cost of debt and board independence and board size, while Lorca et al. (2011) find no the relationship. Ashbaugh-Skaife et al. (2006) show the impact of board independence and board expertise on bonds' credit ratings. They report that more effective board positively relates to higher credit ratings. Inconsistent with those of Ashbaugh-Skaife et al. (2006), empirical findings of Jiraporn et al. (2013) show that an improvement of governance inflates the agency cost of debt and downgrades credit ratings. Effective governance firms tend to exhibit a risky strategy; therefore, bondholders do not view governance mechanism as value-enhancing and demand higher rate of return.

\subsection{Hypotheses Development}

Based on the agency theory, we hypothesize a positive relationship between board effectiveness and the cost of debt that an improvement in board effectiveness induces management to make bad decisions to bondholders, either over-investment or underinvestment. Advising and monitoring roles of board of directors are executed through the board meeting. Effectiveness of corporate boards is improved by the meeting attendance behavior (Lin et al., 2014; Brick \& Chidambaran, 2010; Vafeas, 1999). Attendance of board meetings represents contributed work efforts and the attention of individual board members (Lin et al., 2014; Chou et al., 2013). The relationship between effectiveness of corporate boards and the cost of debt is hypothesized as follows.

H1: The attendance of board meetings improves the effectiveness of corporate boards, and hence associates with the cost of debt.

Board meeting frequency enhances the board effectiveness (Lorca et. al., 2011; Vafeas, 1999). The number of board meetings is a good proxy for board members' monitoring effort. We further examine the relationship between effectiveness of corporate boards and the cost of debt and posit the hypothesis as follows.

H2: A higher number of board meeting improves the effectiveness of corporate boards, and thus associates with the cost of debt.

To extensively examine the association between significant board quality variables suggested by previous studies and the corporate cost of debt, we include the following variables in our study, i.e., the board size (Boone et al. 2007; Anderson et al., 2004), the percentage of independent members on the board (Conyon \& He, 2011; Ashbaugh-Skaife et al., 2006; Bhojraj \& Sengupta, 2003), the percentage of non-executive members on the audit committee (Anderson et al., 2004), the percentage of independent members on the audit committee (Yatim et al., 2006; Carcello \& Neal, 2000), and the board specific skill (Shan \& Mclver, 2011; Ashbaugh-Skaife et al., 2006).

\section{Data}

We collect accounting data and board attributions from DataStream, Bloomberg, and the SEC Filing database. Since only a small number of Thai listed firms issue bonds, the Bloomberg's after-tax weighted average cost of debt of the company is employed. To avoid a potential influence of industry specific regulation, we exclude financial companies as restrictions from the government on the boards of directors and management may have an adverse impact on the cost of debt. Further, accounting practices in the finance industry are different from those in other industries. The period of the study starts from 2007 (the beginning record of the board attendance) to 2016, consisting of 40 unique active companies (176 firm-year observations) and accounting for more than $50.00 \%$ of total market capitalization in 2016.

\section{Methodology}

We follow the empirical model suggested by Chou et al. (2013), who offer a straightforward method to identify the work effort of a director. In this study, we include the percentage of the board attending a meeting. Our empirical model is shown as

$$
\begin{aligned}
& K d_{i, t}=\alpha_{0}+\beta_{1} \text { Board_attend }_{i, t}+\beta_{2} \text { Board_size }_{i, t} \\
& +\beta_{3} \text { Board_meeting }{ }_{i, t}+\beta_{4} \% \text { Independence_board }{ }_{i, t} \\
& +\beta_{5} \% \text { Independence_audit }{ }_{i, t}+\beta_{6} \text { Audit_nonexec }_{i, t} \\
& +\beta_{6} \text { Board_specific_skill }_{i, t}+\beta_{7} \ln \_ \text {asset }{ }_{i, t} \\
& +\beta_{8} \text { Leverage }_{i, t}+\beta_{9} R O A_{i, t}^{i, t}+\beta_{10} \overline{C A} P_{-} I N T_{i, t} \\
& +\beta_{11} \text { Coverage_ratio }{ }_{i, t}+\stackrel{\beta}{12}_{12} M^{10} B_{i, t}+\bar{\varepsilon}_{i, t}
\end{aligned}
$$


where $K d_{i, t}$ is the weighted average cost of debt financing of firm $i$ in year $t$. Board_attend $d_{i, t}$ is the percentage of the director attending a meeting of firm $i$ in year $t$. We follow Lorca et al. (2011) by including the Board_meeting ${ }_{i, t}$, which is the number of board meetings during year $t$ and accounts for the directors' monitoring effort. We also include the board size (Board_size $)$, the percentage of independent directors on the board (\%Independence board $\left.{ }_{i, t}\right)$, and the board specific skill (Board_specific_skill ${ }_{i, t}^{-}$). \%Independence_audit $t_{i, t}$ and Audit_nonexec ${ }_{i, t}$ are the percentage of independent director on audit committee and the percentage of audit committee that are not the firm's executive, consecutively. A firm size measured by the logarithm of total assets ( In_asset $_{i, t}$ ) is added in the model because firms with larger assets are likely to have less risk in the view of debtholders, possibly possessing a low cost of debt. Variables related to the firms' ability to issue debt as well as the default risk are also considered, for example firm's leverage ( Leverage $_{i, t}$ ), measured by the book value of debt to the market value of assets, return on asset $\left(R O A_{i, t}\right)$, and interest coverage ratio (Coverage_ratio $\left.{ }_{i, t}\right)$. To control the effect of difference in the firms' asset structures on cost of borrowing, we include the capital intensity ratio in our model (CAP_INT $)$ because higher capital intensity firms are likely to have a low cost of debt. Lastly, we include the market to book value ratio $\left(M T B_{i, t}\right)$ to control the growth opportunity, as suggested by Bhojraj and Sengupta (2003).

\section{Results}

\subsection{Descriptive Statistics}

Table 1 shows that the mean cost of debt for the firms is 3.179. For the governance variables in our sample, the mean board attendance is $90.792 \%$ of members. The lowest percentage of board members that attended a meeting is about two-thirds (66.99\%). The board meetings are held on average about once a month (12.012 time per year). However, the lowest number of board meetings is four times a year, while the highest is 29 times a year. Almost half of board members are independent of the firm with 37.093 having a specific required skill. On the auditing side, almost $100 \%$ of the audit committee are independent and non-executives of the firm. This means that the board members and the audit committee are able to perform their duties independently.

In addition, we find that the cost of debt negatively correlates with the percentage of the board attending the meeting, the firm size, and the coverage ratio. Also, it indicates that if firms have larger boards and higher numbers of audit committee who are not executives, the firms are more likely to have a higher cost of debt. Also, the results from Table 2 provide a sign of collinearity between independent variables.

Table 1 shows the key variables descriptive statistic. The sample periods are between 2007 and 2016.

\begin{tabular}{|l|c|c|c|c|c|}
\hline Variable & Obs. & Mean & Std. & Min & Max \\
\hline Kd & 173 & 3.179 & 0.771 & 1.420 & 5.420 \\
\hline Board_attend & 173 & 90.792 & 6.337 & 66.990 & 99.170 \\
\hline Board_size & 173 & 14.694 & 2.916 & 8.000 & 28.000 \\
\hline Board_meeting & 173 & 12.012 & 4.930 & 4.000 & 29.000 \\
\hline \%Independence_board & 173 & 46.039 & 14.063 & 22.222 & 94.737 \\
\hline Board_specific_skill & 173 & 37.093 & 14.610 & 6.250 & 85.714 \\
\hline \%Independence_audit & 173 & 98.569 & 5.955 & 66.670 & 100.000 \\
\hline Audit_nonexec & 173 & 97.758 & 7.283 & 50.000 & 100.000 \\
\hline Ln_asset & 173 & 26.146 & 1.480 & 21.836 & 28.700 \\
\hline Leverage & 173 & 0.236 & 0.136 & 0.003 & 0.621 \\
\hline ROA & 173 & 7.078 & 6.613 & -5.070 & 37.198 \\
\hline CAP_INT & 173 & 2.086 & 2.277 & 0.388 & 12.395 \\
\hline Coverage_ratio & 173 & 7.366 & 8.491 & -3.793 & 46.818 \\
\hline MTB & 173 & 9.487 & 33.054 & 0.437 & 295.585 \\
\hline
\end{tabular}


Table 2 shows a pairwise correlation matrix for key variables used in this analysis.

\begin{tabular}{|c|c|c|c|c|c|c|c|c|c|c|c|c|c|}
\hline & $K d$ & $\begin{array}{l}\text { Board } \\
\text { attend }\end{array}$ & $\begin{array}{c}\text { Board_- } \\
\text { size }\end{array}$ & $\begin{array}{l}\text { Board_ } \\
\text { meeting }\end{array}$ & $\begin{array}{c}\% \text { Indepen- } \\
\text { dence_- } \\
\text { board }\end{array}$ & $\begin{array}{c}\text { Board_ } \\
\text { specific_ } \\
\text { skill }\end{array}$ & $\begin{array}{l}\% \text { In- } \\
\text { depen- } \\
\text { dence_ } \\
\text { audit }\end{array}$ & $\begin{array}{c}\text { Audit_- } \\
\text { nonexec }\end{array}$ & $\begin{array}{l}\mathrm{Ln} \\
\text { asset }\end{array}$ & $\begin{array}{l}\text { Lever- } \\
\text { age }\end{array}$ & $R O A$ & $\begin{array}{l}\text { CAP } \\
\text { INT }\end{array}$ & $\begin{array}{c}\text { Coverage } \\
\text { ratio }\end{array}$ \\
\hline$K d$ & 1.000 & & & & & & & & & & & & \\
\hline Board_attend & $-0.151^{*}$ & 1.000 & & & & & & & & & & & \\
\hline Board_size & $0.231^{*}$ & -0.092 & 1.000 & & & & & & & & & & \\
\hline Board_meeting & 0.055 & 0.142 & $0.272^{*}$ & 1.000 & & & & & & & & & \\
\hline $\begin{array}{l}\text { \%Independence_ } \\
\text { board }\end{array}$ & 0.005 & $0.170^{*}$ & $0.187^{*}$ & $0.366^{*}$ & 1.000 & & & & & & & & \\
\hline $\begin{array}{l}\text { Board_specific_ } \\
\text { skill }\end{array}$ & -0.013 & -0.123 & $-0.235^{\star}$ & $-0.335^{*}$ & $-0.458^{*}$ & 1.000 & & & & & & & \\
\hline $\begin{array}{l}\text { \%Independence_ } \\
\text { audit }\end{array}$ & 0.048 & 0.070 & $0.149^{*}$ & 0.146 & 0.072 & -0.105 & 1.000 & & & & & & \\
\hline Audit_nonexec & $0.246^{*}$ & 0.025 & -0.107 & -0.137 & -0.089 & $0.149^{*}$ & -0.050 & 1.000 & & & & & \\
\hline Ln_asset & $-0.127^{\star}$ & 0.083 & $0.425^{\star}$ & $0.432^{*}$ & $0.349^{*}$ & $-0.289^{\star}$ & 0.124 & -0.012 & 1.000 & & & & \\
\hline Leverage & $0.216^{*}$ & $-0.253^{*}$ & -0.005 & $-0.203^{*}$ & -0.073 & -0.001 & -0.036 & -0.098 & -0.020 & 1.000 & & & \\
\hline$R O A$ & 0.056 & -0.118 & $-0.257^{*}$ & $-0.291^{*}$ & -0.145 & $0.341^{*}$ & -0.087 & $0.267^{*}$ & $-0.327^{*}$ & $-0.150^{*}$ & 1.000 & & \\
\hline CAP_INT & $0.133^{*}$ & -0.106 & -0.032 & -0.007 & 0.093 & 0.145 & 0.004 & -0.047 & -0.032 & -0.099 & 0.010 & 1.000 & \\
\hline Coverage_ratio & -0.025 & $-0.207^{*}$ & -0.003 & $-0.154^{*}$ & -0.096 & 0.063 & 0.027 & 0.037 & -0.030 & $-0.297^{*}$ & 0.102 & 0.008 & 1.000 \\
\hline MTB & 0.052 & 0.087 & $-0.158^{*}$ & 0.072 & -0.020 & -0.047 & 0.033 & -0.005 & $-0.280^{*}$ & 0.085 & $0.147^{*}$ & -0.007 & 0.017 \\
\hline
\end{tabular}

Note: ${ }^{* * *},{ }^{* *}$ and ${ }^{*}$ indicates significant at $1 \%, 5 \%$ and $10 \%$ level of significance based on t-statistics

Table 3 shows a variance inflated index (VIF) for all variable used in this analysis.

\begin{tabular}{|l|c|c|}
\hline Variable & VIF & 1/VIF \\
\hline Coverage_ratio & 3.26 & 0.289264 \\
\hline ROA & 3.14 & 0.318874 \\
\hline Ln_asset & 2.2 & 0.453869 \\
\hline Board_meeting & 2.03 & 0.493414 \\
\hline Board_size & 1.95 & 0.514077 \\
\hline MTB & 1.81 & 0.551232 \\
\hline \%Independence_board & 1.79 & 0.558555 \\
\hline Board_specific_skill & 1.53 & 0.65293 \\
\hline Leverage & 1.5 & 0.665644 \\
\hline Board_attend & 1.22 & 0.819092 \\
\hline Audit_nonexec & 1.18 & 0.844326 \\
\hline CAP_INT & 1.12 & 0.893929 \\
\hline$\%$ Independence_audit & 1.07 & 0.934892 \\
\hline Mean & 1.83 & \\
\hline
\end{tabular}


Table 4 show the univariate and multivariate regression analysis according to Eq. (1).

$K d_{i, t}=\alpha_{0}+\beta_{1}$ Board_attend ${ }_{i, t}+\beta_{2}$ Board_size $_{i, t}+\beta_{3}$ Board_meeting ${ }_{i, t}+\beta_{4} \%$ Independence_board ${ }_{i, t}+\beta_{5} \%$ Independence_audit

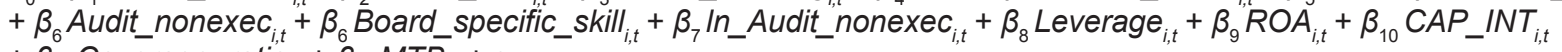

$+\beta_{11}$ Coverage_ratio $i, t+\beta_{12} M_{T B}+\varepsilon_{i, t}$

The dependence variable is the cost of debt-Kd. The explanatory variables are the board variables including Board_attend, Board_size, Board_meeting, \%Independence_board, \%Independence_audit, Audit_nonexec, Board_specific_skill for each firm in our sample. The control variables are log of asset size_In_asset, leverage, ROA, CAP_INT—capital intensity, coverage ratio, and MTB-market to book ratio.

\begin{tabular}{|c|c|c|c|c|c|c|c|c|}
\hline & $K d$ & $K d$ & $K d$ & $K d$ & $K d$ & $K d$ & $K d$ & $K d$ \\
\hline \multirow[t]{2}{*}{ Board_attend } & -0.0082 & & & & & & & -0.0060 \\
\hline & $(-0.87)$ & & & & & & & $(-0.67)$ \\
\hline \multirow[t]{2}{*}{ Board_size } & & $0.0752^{\star \star \star}$ & & & & & & $0.0820^{* * *}$ \\
\hline & & $(2.92)$ & & & & & & (2.73) \\
\hline \multirow[t]{2}{*}{ Board_meeting } & & & $0.0407^{* * \star}$ & & & & & $0.0340^{*}$ \\
\hline & & & $(2.78)$ & & & & & (1.81) \\
\hline \multirow[t]{2}{*}{$\begin{array}{l}\% \text { Independence } \\
\text { board }\end{array}$} & & & & 0.0022 & & & & 0.0069 \\
\hline & & & & $(0.42)$ & & & & $(1.32)$ \\
\hline \multirow[t]{2}{*}{$\begin{array}{l}\% \text { Independence_ } \\
\text { audit }\end{array}$} & & & & & -0.0118 & & & -0.0037 \\
\hline & & & & & $(-1.21)$ & & & $(-0.36)$ \\
\hline \multirow[t]{2}{*}{ Audit_nonexec } & & & & & & $0.0353^{* * *}$ & & $0.0371^{* * *}$ \\
\hline & & & & & & $(4.46)$ & & $(4.79)$ \\
\hline \multirow[t]{2}{*}{ Board_specific_skill } & & & & & & & 0.00197 & 0.00692 \\
\hline & & & & & & & $(0.45)$ & $(1.61)$ \\
\hline \multirow[t]{2}{*}{ In_asset } & -0.0770 & -0.0571 & -0.118 & 0.00212 & 0.0191 & -0.0243 & 0.0175 & $-0.235^{* * *}$ \\
\hline & $(-1.19)$ & $(-0.73)$ & $(-1.64)$ & $(0.03)$ & $(0.25)$ & $(-0.39)$ & $(0.24)$ & $(-3.53)$ \\
\hline \multirow[t]{2}{*}{ Leverage } & $0.933^{*}$ & $1.049^{* *}$ & $1.047^{*}$ & $1.078^{*}$ & $1.014^{*}$ & $1.342^{* *}$ & $1.082^{*}$ & $1.449^{* * *}$ \\
\hline & $(1.73)$ & $(2.04)$ & $(1.92)$ & $(1.94)$ & $(1.84)$ & $(2.43)$ & $(1.92)$ & $(2.58)$ \\
\hline \multirow[t]{2}{*}{$R O A$} & 0.0202 & $0.0341^{* *}$ & $0.0322^{* *}$ & $0.0302^{*}$ & $0.0293^{* *}$ & 0.0164 & $0.0272^{*}$ & 0.0224 \\
\hline & $(1.41)$ & $(2.30)$ & $(2.11)$ & $(1.94)$ & $(1.98)$ & $(1.16)$ & $(1.77)$ & $(1.59)$ \\
\hline \multirow[t]{2}{*}{ CAP_INT } & $-0.0629^{* *}$ & $-0.0550^{* *}$ & $-0.0651^{* * *}$ & $-0.0545^{\star *}$ & $-0.0527^{* *}$ & $-0.0656^{\star * *}$ & $-0.0539^{* *}$ & $-0.0701^{* * *}$ \\
\hline & $(-2.58)$ & $(-2.57)$ & $(-2.94)$ & $(-2.38)$ & $(-2.26)$ & $(-2.80)$ & $(-2.28)$ & $(-2.71)$ \\
\hline \multirow[t]{2}{*}{ Coverage_ratio } & $-0.0299^{* * *}$ & $-0.0297^{* \star *}$ & $-0.0369^{* * *}$ & $-0.0304^{* * *}$ & $-0.0305^{\star * *}$ & $-0.0290^{* * *}$ & $-0.0295^{\star \star *}$ & $-0.0364^{* * *}$ \\
\hline & $(-2.78)$ & $(-2.78)$ & $(-3.15)$ & $(-2.71)$ & $(-2.77)$ & $(-2.73)$ & $(-2.73)$ & $(-3.17)$ \\
\hline \multirow[t]{2}{*}{ MTB } & 0.000438 & 0.000700 & -0.00162 & 0.000862 & 0.00124 & 0.000977 & 0.00130 & -0.00182 \\
\hline & $(0.33)$ & $(0.51)$ & $(-1.05)$ & $(0.56)$ & $(0.91)$ & $(0.78)$ & $(0.94)$ & $(-0.94)$ \\
\hline \multirow[t]{2}{*}{$\beta_{0}$} & $5.962^{\star * *}$ & $3.435^{*}$ & $5.776^{* * *}$ & 2.931 & $3.774^{*}$ & 0.297 & 2.563 & $4.353^{* *}$ \\
\hline & $(3.01)$ & $(1.73)$ & $(3.07)$ & $(1.41)$ & $(1.87)$ & $(0.16)$ & $(1.30)$ & $(2.14)$ \\
\hline $\mathrm{R}^{2}$ & 0.152 & 0.170 & 0.183 & 0.125 & 0.130 & 0.231 & 0.125 & 0.354 \\
\hline
\end{tabular}

Note: ${ }^{* * *},{ }^{* *}$ and ${ }^{*}$ indicates significant at $1 \%, 5 \%$ and $10 \%$ level of significance based on t-statistics 
As a consequence, we estimate the variance inflation factors (VIF) for all independent variables. Table 3 shows that all of the estimated VIF values fall within acceptable levels - below 3.5 for all variables.

\subsection{Multivariate Regression Analysis}

Table 4 reports the regression analysis. Columns $1-7$, we regress the cost of debt on the governance variables and control variables. Column 8 , we report the multivariate regression analysis in equation (1). In the separate regressions, we find that most of the control variables are significant. In addition, we find strong evidence that the board size (coefficient $0.0752 ; \mathrm{p}<0.01$ ) and the number of board meetings (coefficient 0.0407 ; $\mathrm{p}<0.01$ ) are positively associated with the cost of debt and are significant. This preliminary result suggests that the larger the board size and the more frequent the board meetings show the higher the cost of debt. Moreover, we find the same positive relationship between the cost of debt and the percentage of non-executive as member of audit committee (coefficient $0.0353 ; \mathrm{p}<0.01$ ). Our findings support the sub-optimal investment hypothesis suggesting that the better the quality of governance, the higher the cost of debt for the firm. Also, our findings are consistent with Jiraporn et al. (2013). Column 7, the result remains unchanged for both board variables and the control variables. More specifically, we find positive relationships between the cost of debt and the board effectiveness - the board size, the number of board meetings, and the percentage of non-executives on the audit committee. Among these three relationships, the percentage of non-executives on the audit committee has a higher impact on the cost of debt. The economic significance of the percentage of non-executives on the audit committee is that every $1 \%$ increase in the proportion of non-executives on the audit committee causes a $0.0371 \%$ increase to the cost of debt.

\section{Possible Endogeneity Issues}

One problem in studies of panel data is an endogeneity issue. As a consequence, we investigate the possibility of an endogeneity relationship between the cost of debt and governance variables. Prior literature suggests that the causality between corporate governance and the cost of debt is much more likely to come from the governance side (Ashbaugh-Skaife et al., 2006; Jiraporn et al., 2013; Lorca et al., 2011). However, it is possible that the cost of debt could affect the governance variables. To determine the endogeneity, we use Durbin-Wu-Hausman test for all governance variables. Based on the p-value, we cannot reject the null hypothesis that variables are exogenous ( $\mathrm{p}$-value $=0.4459)$. In an unreported test, although we perform the Durbin-Wu-Hausman tests on all governance variables - the percentage of board attending meeting, board size, the percentage of independence board, the board specific skill separately, we cannot reject the null hypothesis that the variable is exogenous. Further, we perform a two-stage least-square procedure to alleviate this endogeneity, if it exists (Jiraporn et al., 2013; Klock et al., 2005; Lorca et al., 2011). In our analysis, we use lagged one year of board variables as the instrumental variables as shown in Eq. (2), since the value of these governance variables are more likely to persist. As a consequence, the lagged one year of these variables can be a good predictor for the variables of the current year (Caramanis \& Lennox, 2008; Lorca et al., 2011). The Board variable $_{i, t}$, are Board ${ }_{\text {attend } i, t}$, Board $_{\text {size } i, t}$, Board $_{\text {meeting } i, t}$, and $\%$ Independence_board ${ }_{i, t}$. We report the results from the two-stage least-square procedure in Table 5. Overall, we find consistent results as before

$$
\begin{aligned}
\text { Board variable }_{i, t}= & \beta_{0}+\beta_{1} \text { Board variable }_{i, t-1}+\beta_{2} \text { Kd }_{i, t} \\
& +\beta_{7} \text { ln_asset }_{i, t}+\beta_{8} \text { Leverage }_{i, t} \\
& +B_{9} \text { ROA }_{i, t}+\beta_{10} \text { CAP_INT }_{i, t} \\
& +\beta_{11} \text { TIE }_{i, t}+\beta_{12} \text { MTB }_{i, t}+\varepsilon_{i, t}
\end{aligned}
$$

Our findings support the sub-optimal investment hypothesis in that the improved board effectiveness causes higher cost of debt. We find that two out of four board variables are positively significant. To be more specific, we find that the board size is positively related to the cost of debt. Since the board of directors play a major role in monitoring and control the action of executive, the larger board size enable firm to increase monitoring efficiency and enjoy greater board expertise which will be benefit to shareholder. In addition, as board size, the higher number of board meeting can enhance the monitoring function of board. As the consequence, bondholder requires additional debt financing.

\section{Conclusions}

In this study, we find that the effectiveness of governance has a positive effect on the cost of debt financing in one emerging market - Thailand. Our analysis is based on an incomplete market structure, political and economic uncertainties, weak regulations and low-quality auditing systems. Given the emerging condition, our findings here are consistent with the sub-optimal investment hypothesis in that the improved governance leads to a higher cost of borrowing. More specifically, our results suggest that two board variables (the board size, the number of board meeting) and the percentage of non-executives on the audit committee are associated with the cost of debt. 
Table 5 show the result of 2SLS analysis. The dependence variable is the cost of debt-Kd. Where the board variables-The explanatory variables_the board Board_attend, Board_size, Board_meeting, \%Independence_board, \%Independence_audit, Autit_nonexec, Board_specific_skill are estimated using Eq.(2) in the first statge:

Board variable $_{i, t},=\beta_{0}+\beta_{1}$ Board variable $_{i, t-1}+\beta_{2} K d_{i, t}$ $+\beta_{7}$ In_asset ${ }_{i, t}+\beta_{8}$ In_Leverage ${ }_{i, t}$

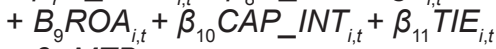
$+\beta_{12} M T B_{i, t}+\varepsilon_{i, t^{*}}$

The control variables are the same as in previous section

\begin{tabular}{|c|c|}
\hline & $K d$ \\
\hline \multirow[t]{2}{*}{ Board_attend } & 0.00889 \\
\hline & $(0.57)$ \\
\hline \multirow[t]{2}{*}{ Board_size } & $0.157^{* * *}$ \\
\hline & $(3.60)$ \\
\hline \multirow[t]{2}{*}{ Board_meeting } & $0.0532^{* *}$ \\
\hline & $(2.09)$ \\
\hline \multirow[t]{2}{*}{ \%Independence_board } & 0.00544 \\
\hline & $(0.99)$ \\
\hline \multirow[t]{2}{*}{$\%$ Indepe $\widehat{\text { dence _audit }}$} & -0.0161 \\
\hline & $(-1.05)$ \\
\hline \multirow[t]{2}{*}{ Audit_nonexec } & $0.0601^{* * *}$ \\
\hline & $(5.96)$ \\
\hline \multirow[t]{2}{*}{ Board_specific_skill } & 0.00284 \\
\hline & $(0.65)$ \\
\hline \multirow[t]{2}{*}{ In_asset } & $-0.350^{* * *}$ \\
\hline & $(-5.04)$ \\
\hline \multirow[t]{2}{*}{ Leverage } & $1.746^{* * *}$ \\
\hline & $(2.82)$ \\
\hline \multirow[t]{2}{*}{ ROA } & $0.0275^{*}$ \\
\hline & $(1.90)$ \\
\hline \multirow[t]{2}{*}{ CAP_INT } & $-0.0638^{* *}$ \\
\hline & $(-2.22)$ \\
\hline \multirow[t]{2}{*}{ Coverage_ratio } & $-0.0370^{* * *}$ \\
\hline & $(-3.22)$ \\
\hline \multirow[t]{2}{*}{ MTB } & $-0.00366^{*}$ \\
\hline & $(-1.73)$ \\
\hline \multirow[t]{2}{*}{$\beta_{0}$} & 3.778 \\
\hline & $(1.60)$ \\
\hline
\end{tabular}

Note: ${ }^{* * *},{ }^{* *}$ and ${ }^{*}$ indicates significant at $1 \%, 5 \%$ and $10 \%$ level of significance based on t-statistics

\section{References}

Adams, R. B., \& Ferreira, D. (2008). Do directors perform for pay? Journal of Accounting and Economics, 46(1), 154-171.

Anderson, R. C., Mansi, S. A., \& Reeb, D. M. (2004). Board characteristics, accounting report integrity, and the cost of debt. Journal of Accounting and Economics, 37(3), 315-342.

Ashbaugh-Skaife, H., Collins, D. W., \& LaFond, R. (2006). The effects of corporate governance on firms' credit ratings. Journal of Accounting and Economics, 42(1-2), 203-243.

Bhojraj, S., \& Sengupta, P. (2003). Effect of corporate governance on bond ratings and yields: The role of institutional investors and outside directors. The Journal of Business, 76(3), 455-475.

Boone, A. L., Field, L. C., Karpoff, J. M., \& Raheja, C. G. (2007). The determinants of corporate board size and composition: An empirical analysis. Journal of Financial Economics, 85(1), 66-101.

Bradley, M., \& Chen, D. (2015). Does board independence reduce the cost of debt?, Financial Management, 44(1), 15-47.

Brick, I. E., \& Chidambaran, N. (2010). Board meetings, committee structure, and firm value. Journal of Corporate Finance, 16(4), 533-553.

Caramanis, C., \& Lennox, C. (2008). Audit effort and earnings management. Journal of Accounting and Economics, 45(1), 116-138.

Carcello, J. V., \& Neal, T. L. (2000). Audit committee composition and auditor reporting. The Accounting Review, 75(4), 453-467.

Chou, H.-I, Chung, H., \& Yin, X. (2013). Attendance of board meetings and company performance: Evidence from Taiwan. Journal of Banking \& Finance, 37(11), 4157-4171.

Conyon, M. J., \& He, L. (2011). Executive compensation and corporate governance in China. Journal of Corporate Finance, 17(4), 1158-1175.

Denis, D. K., \& McConnell, J. J. (2003). International corporate governance. Journal of Financial \& Quantitative Analysis, $38(1), 1-36$.

Fama, E. F., \& Miller, M. H. (1972). The theory of finance. New York, NY: Holt Rinehart \& Winston.

Fields, L. P., Fraser, D. R., \& Subrahmanyam, A. (2012). Board quality and the cost of debt capital: The case of bank loans. Journal of Banking \& Finance, 36(5), 1536-1547.

Garner, J., Kim, T., \& Kim, W.Y. (2017). Boards of directors: A literature review. Managerial Finance, 43(10), 1189-1198.

Ghouma, H., Ben-Nasr, H., \& Yan, R. (2018). Corporate governance and cost of debt financing: Empirical evidence from Canada. The Quarterly Review of Economics and Finance, 67,138-148. https://doi.org/10.1016/j.qref2017.06.004

Han, S.-H., Kang, K., \& Shin, Y. S. (2016). Bond Ratings, Corporate Governance, and Cost of Debt: The Case of Korea. Journal of 
Asian Finance, Economics and Business, 3(3), 5-15. https://doi. org/10.13106/jafeb.2016.vol3.no3.5.

Hashim, H. A., \& Amrah, M. (2016). Corporate governance mechanisms and cost of debt: Evidence of family and nonfamily firms in Oman. Managerial Auditing Journal, 31(3), 314-336.

Jensen, M. C. (1993). The Modern Industrial Revolution, Exit, and the Failure of Internal Control Systems. The Journal of Finance, 48(3), 831-880.

Jensen, M. C., \& Meckling, W. H. (1976). Theory of the firm: Managerial behavior, agency costs and ownership structure. Journal of Financial Economics, 3(4), 305-360.

Jiraporn, P., Chatjuthamard, P., Tong, S., \& Kim, Y. S. (2015). Does corporate governance influence corporate risk-taking? Evidence from the Institutional Shareholders Services (ISS). Finance Research Letters, 13, 105-112.

Jiraporn, P., Chintrakarn, P., Kim, J.-C., \& Liu, Y. (2013). Exploring the agency cost of debt: Evidence from the ISS governance standards. Journal of Financial Services Research, 44(2), 205-227.

Klock, M. S., Mansi, S. A., \& Maxwell, W. F. (2005). Does corporate governance matter to bondholders? Journal of Financial and Quantitative Analysis, 40(4), 693-719.

Lasfer, M. A. (1995). Agency costs, taxes and debt: the UK evidence. European Financial Management, 1(3), 265-285.

Lin, Y.-f., Yeh, Y. M. C., \& Yang, F.-m. (2014). Supervisory quality of board and firm performance: a perspective of board meeting attendance. Total Quality Management \& Business Excellence, 25(3-4), 264-279.

Lorca, C., Sánchez-Ballesta, J. P., \& García-Meca, E. (2011). Board effectiveness and cost of debt. Journal of Business Ethics, 100(4), 613-631.

Ortiz-Molina, H. (2006). Top management incentives and the pricing of corporate public debt. Journal of Financial and Quantitative Analysis, 41(2), 317-340.
Pham, P. K., Suchard J., and Zein, J. (2012). Corporate govenance and the cost of capital: Evidence from Australian companies. Journal of Applied Corporate Finance, 24(3), 84-93.

Prommin, P., Jumreornvong, S., Jiraporn, P. (2014). The effect of corporate governance on stock liquidity: the case of Thailand. The International Review of Economics \& Finance. 32, 132-142.

Sengupta, P. (1998). Corporate disclosure quality and the cost of debt. Accounting Review, 73(4), 459-474.

Shan, Y. G., \& McIver, R. P. (2011). Corporate governance mechanisms and financial performance in China: Panel data evidence on listed non financial companies. Asia Pacific Business Review, 17(3), 301-324.

Vafeas, N. (1999). Board meeting frequency and firm performance. Journal of Financial Economics, 53(1), 113-142.

Vijayakumaran, S., \& Vijayakumaran, R. (2019a). Corporate Governance and Capital Structure Decisions: Evidence from Chinese Listed Companies. Journal of Asian Finance, Economics and Business, 6(3), 67-79. https://doi.org/10.13106/ jafeb.2019.vol6.no3.67

Vijayakumaran, S., \& Vijayakumaran, R. (2019b). Debt Maturity and the Effects of Growth Opportunities and Liquidity Risk on Leverage: Evidence from Chinese Listed Companies. Journal of Asian Finance, Economics and Business, 6(3), 27-40. https:// doi.org/10.13106/jafeb.2019.vol6.no3.27

Wattanatorn, W., \& Nathaphan, S. (2019). Do bank-affiliated funds perform better than the others: the higher moment approach. Asia-Pacific Journal of Accounting \& Economics. [Online First]. https://doi.org/10.1080/16081625.2019.1658528

Wattanatorn, W., Padungsaksawasdi, C., Chunhachinda, P., \& Nathaphan, S. (2020). Mutual fund liquidity timing ability in the higher moment framework. Research in International Business and Finance, 51, 101105.

Yatim, P., Kent, P., \& Clarkson, P. (2006). Governance structures, ethnicity, and audit fees of Malaysian listed firms. Managerial Auditing Journal, 21(7), 757-782. 